\title{
Bacterial diversity and community structure in acid mine drainage from Dabaoshan Mine, China
}

\author{
Yu Yang ${ }^{1,2}$, Min-xi Wan ${ }^{1}$, Wu-yang Shi ${ }^{1}$, Hong Peng ${ }^{1}$, Guan-zhou Qiu ${ }^{1,2}$, \\ Ji-zhong Zhou ${ }^{3}$, Xue-duan Liu ${ }^{1,2, *}$ \\ ${ }^{1}$ School of Minerals Processing and Bioengineering, Central South University, 25 South Lushan Road, Changsha, \\ Hunan 410083, China \\ ${ }^{2}$ Key Laboratory of Biometallurgy, Ministry of Education, 25 South Lushan Road, Changsha, Hunan 410083, China \\ ${ }^{3}$ Department of Botany and Microbiology, 770 Van Vleet Oval, University of Oklahoma, Norman, \\ Oklahoma 73019-4110, USA
}

\begin{abstract}
Three samples of acid mine drainage (AMD) collected from Dabaoshan Mine (Guangdong Province, China) were studied. In addition to physico-chemical analyses, bacterial diversities and community structures of these samples were described at genetic level by amplified ribosomal DNA restriction analysis (ARDRA). A total of 60 different ARDRA patterns were obtained from 377 clones and were studied as operational taxonomic units (OTUs), which were re-amplified and sequenced. The sequence data and phylogenetic analysis showed that Acidithiobacillus ferrooxidans represented $88.0 \%$ of the bacterial population in Sample LC. However, Samples JX and FS contained more diverse colonies of bacteria, such as Leptospirillum ferrooxidans (JX: 16.9\%, FS: 39.1\%), Acidiphilum sp. (JX: 38.7\%, FS: $25.8 \%$ ) and A. ferrooxidans (JX: 12.1\%, FS: 10.2\%). These diversities were characterized by the reciprocal of Simpson's index $(1 / D)$ and correlated with the concentrations of ferrous iron and toxic ions in AMD.
\end{abstract}

KEY WORDS: Bacterial diversity $\cdot$ Microbial community $\cdot$ Acid mine drainage $\cdot$ Amplified ribosomal DNA restriction analysis

\section{INTRODUCTION}

Recently, some microorganisms that can grow in extreme circumstances have attracted considerable attention because of their unusual physiology, ecological properties and some important biotechnological applications (Russell 2000, Margesin \& Schinner 2001, Rawlings 2002). Acid mine drainage (AMD) environments are especially interesting because, in general, the low $\mathrm{pH}$ of the habitat is the consequence of microbial metabolism (Gonzalez-Toril et al. 2003a) and not a condition imposed by the system, as is the case in many other extreme environments (e.g. temperature, ionic strength, high $\mathrm{pH}$, radiation, pressure).

AMD is derived from mine dissolution by a series of complex geochemical and microbial reactions when water comes in contact with the mine (Johnson \& Hallberg 2003). The functions of some extremophiles that can grow and develop under AMD are commonly considered as important for mine dissolution. An important biotechnological application of these extremophiles is bioleaching. The application is simple and provides effective technology for metal extraction from low-grade ores and mineral concentrates, and is based on the activities of some chemolithotrophic bacteria, which convert insoluble metal sulfides into soluble metal sulfates and are tolerant to metal ions (Suzuki 2001). For decades, chemolithotrophic prokaryotes such as Acidithiobacillus ferrooxidans (formerly known as Thiobacillus ferrooxidans; Kelly \& Wood 2000) and Leptospirillum ferrooxidans have been known to enhance acid production in metal-leaching environments by oxidizing ferrous iron and replenishing the oxidant ferric iron (Sand et al. 1995). Furthermore, they have long been regarded as the principal acidophilic sulfur- and iron-oxidizing microbes, and consequently they have been the focus for research on bioleaching for a long time. Several studies on the distribution of these species in leaching tanks, soils and aquatic environments 
(e.g. Coram \& Rawlings 2002, Kormas et al. 2006) have been conducted.

New studies (since the 90s) on AMD from diverse geographical locations have revealed that many uncultured bacteria might be very important in the generation of acidic environments (Golyshina et al. 2000), and that AMD supports a diverse range of iron- and sulfuroxidizing chemolithotrophs as well as heterotrophic microorganisms (Johnson 1998). Community structure varies among diverse geographical locations, revealing that AMD niches and changes in dominant bacterial species are affected by geographical conditions.

Studies of bacterial diversity and community structure in diverse AMD can help us to reveal principal bacterial species for mine dissolution in different geographical conditions, and the factors that affect such bacterial communities. To date, although there are many existing reports on bacterial ecology in AMD, to the best of our knowledge such studies in Chinese mines are rare. In this study, we investigated the bacterial and geochemical characteristics of 3 AMD sites in Dabaoshan Mine, Guangdong Province, China. The genomic DNA of the bacterial community at each site was extracted. Subsequently, Amplified Ribosomal DNA Restriction Analysis (ARDRA) was used to analyze the bacterial communities that occur at these sites, and the findings were correlated with the determined geochemistry and mineralogy of each site.

\section{MATERIALS AND METHODS}

Study site, sample collection and physicochemical analyses. Dabaoshan Mine $\left(24^{\circ} 31^{\prime} 37^{\prime \prime} \mathrm{N}\right.$, $113^{\circ} 42^{\prime} 49^{\prime \prime} \mathrm{E}$ ) is located in the mountainous area of the northern part of Guangdong Province, China. It is a large, multi-metallic mineral deposit: the top of the main ore body appears to be a limonite body, while the lower body contains copper sulphur compounds and associated tungsten, bismuth, molybdenum, gold and silver metal ores. As with most metal deposits, the strata contain pyrite $\left(\mathrm{FeS}_{2}\right)$ and various other metal sulphide ores.

All AMD samples were collected from different sites in Dabaoshan Mine in August 2005. The first sample (JX) was taken from the mine tunnel located $100 \mathrm{~m}$ below the surface and at an elevation of $530 \mathrm{~m}$. The site was dank and abandoned. The second sample (LC) was collected from the open-cast mining area in Dabaoshan Mine, which was in operation at that time. The third sample (FS) was collected from a site where many abandoned ores were deposited. All AMD samples were filtered on site through $0.2 \mu \mathrm{m}$ nylon filters (Jinjing) with a vacuum pump, and water samples were then immediately transferred into anaerobic jars. Sediment on the filters was collected and kept at $-20^{\circ} \mathrm{C}$. The filtrate of AMD samples was used for chemical analyses. Physicochemical analyses of the water samples were performed at the Testing Center of Central South University. Flame atomic absorption spectrometry was used for measurements of metal ion, and $\mathrm{pH}$ was measured with a $\mathrm{pH}$ meter (PHS-25, Leici).

DNA extraction and purification. The microorganisms of AMD samples were isolated in sediment after filtration through $0.2 \mu \mathrm{m}$ nylon filters. For each site, genomic DNA of the bulk community was extracted from $5 \mathrm{~g}$ of sediment following the protocols described by Zhou et al. (1996) and Hurt et al. (2001).

The $5 \mathrm{~g}$ of sediment was mixed with $13.5 \mathrm{ml}$ of extraction buffer $(0.1 \mathrm{M}$ phosphate $[\mathrm{pH} 8.0], 0.1 \mathrm{M}$ EDTA, $1.5 \mathrm{M} \mathrm{NaCl}, 1 \% \mathrm{CTAB}$ ) and added to $50 \mu \mathrm{l}$ Proteinase $\mathrm{K}$ (QIAGEN, $10 \mathrm{mg} \mathrm{ml}^{-1}$ ) in $50 \mathrm{ml}$ centrifuge tubes, and then incubated at $37^{\circ} \mathrm{C}$ for $30 \mathrm{~min}$. Next, $1 \mathrm{ml}$ of $20 \%$ SDS was added and mixed gently, followed by further incubation at $65^{\circ} \mathrm{C}$ for $2 \mathrm{~h}$ with gentle inversion every 15 to $30 \mathrm{~min}$. The mixture was centrifuged at $4000 \times g$ for $5 \mathrm{~min}$ at $25^{\circ} \mathrm{C}$, and the supernatant then transferred into a new $50 \mathrm{ml}$ centrifuge tube. Following resuspension of the soil pellet by vortexing in $4.5 \mathrm{ml}$ extraction buffer, $0.5 \mathrm{ml} 20 \%$ SDS was added to the mixture and mixed gently. Samples were then incubated at $65^{\circ} \mathrm{C}$ for 15 min followed by centrifugation at $4000 \times g$ for $5 \mathrm{~min}$ at $25^{\circ} \mathrm{C}$, and the supernatant was then collected and combined with the previous supernatant. The supernatant was extracted with an equal volume of chloroform, and gently mixed and then centrifuged at $4000 \times g$ for $20 \mathrm{~min}$. After the supernatant was collected, 0.6 volumes of 2 -isopropanol was added to the supernatant, which was then gently mixed and left to stand at room temperature overnight. Samples were centrifuged at $16000 \times g$ for $30 \mathrm{~min}$ at $25^{\circ} \mathrm{C}$. The pellet was washed with $70 \%$ ethanol, centrifuged at $4000 \mathrm{rpm}$ for $10 \mathrm{~min}$ at $25^{\circ} \mathrm{C}$, and then dissolved in 200 to $500 \mu \mathrm{l}$ of sterile water. The quality of genomic DNA was analyzed by agarose gel electrophoresis and purified using Wizard DNA CleanUp Kit (Promega).

16S rRNA gene amplification and cloning. Two primers were used to amplify approximately $1300 \mathrm{bp}$ of a consensus 16S rRNA gene fragment: forward primer 63F (5'-CAGGCCTAACACATGCAAGTC-3') and reverse primer 1387R (5'-GGGCGGWGTGTACAAGGC -3') (Marchesi et al. 1998).

The PCR mixtures $(50 \mu \mathrm{l})$ contained $10 \mathrm{pmol}$ of each appropriate primer, $2 \mu \mathrm{l}$ of genomic DNA $\left(\sim 0.1 \mu \mathrm{g} \mathrm{\mu l} \mathrm{l}^{-1}\right)$, $5 \mu \mathrm{l}$ of $10 \times$ dNTP $\left(2 \mathrm{mmol} \mathrm{l}^{-1}\right.$ each), $5 \mu \mathrm{l}$ of $10 \times$ PCR buffer, and $0.5 \mathrm{U}$ of AmpliTaq Gold DNA polymerase (Perkin Elmer). Thermal cycling was carried out using a Whatman Biometra T1 Thermocycler programmed for an initial step of $5 \mathrm{~min}$ at $94^{\circ} \mathrm{C}$, followed by 30 cycles of 
$45 \mathrm{~s}$ at $94^{\circ} \mathrm{C}, 45 \mathrm{~s}$ at $65^{\circ} \mathrm{C}, 90 \mathrm{~s}$ at $72^{\circ} \mathrm{C}$, and then $7 \mathrm{~min}$ at $72^{\circ} \mathrm{C}$. The PCR products were visualized by $1.0 \%$ lowmelting-point agarose gel electrophoresis, and purified using Wizard DNA Clean-Up Kit (Promega).

The purified 16S rRNA gene fragments were ligated into the vector PCR2.1 TOPO, then transformed into E. coli TOP10F' competent cells according to the manufacturers' instructions (Invitrogen). Recombinants were identified based on blue-white screening, and grown overnight in Luria-Bertani (LB) agar plates containing appropriate amounts of ampicillin, X-gal and IPTG (Isopropylthio- $\beta$-D-galactoside at $37^{\circ} \mathrm{C}$. Next, 168 to 176 white colonies from each of these 3 libraries were randomly selected, and the recombinant plasmids containing 16S rRNA gene fragments were reamplified by PCR using the vector primers M13F (5'-GTAAAACGACGGCCAGTG-3') and M13R (5'GGAAACAGCTATGACCATG-3'). The PCR mixtures $(50 \mu \mathrm{l})$ also contained $10 \mathrm{pmol}$ of each appropriate primer, $2 \mu \mathrm{l}$ of plasmid DNA $\left(\sim 0.1 \mu \mathrm{g} \mathrm{ll}^{-1}\right), 5 \mu \mathrm{l}$ of $10 \times$ dNTP ( $2 \mathrm{mmol} \mathrm{l}^{-1}$ each), $5 \mu$ l of $10 \times$ PCR buffer, and $0.5 \mathrm{U}$ of AmpliTaq Gold DNA polymerase (Perkin Elmer). Thermal cycling was carried out using a Whatman Biometra T1 Thermocycler programmed for an initial step of 3 min at $94^{\circ} \mathrm{C}$, followed by 30 cycles of $45 \mathrm{~s}$ at $94^{\circ} \mathrm{C}, 45 \mathrm{~s}$ at $55^{\circ} \mathrm{C}, 90 \mathrm{~s}$ at $72^{\circ} \mathrm{C}$, and then $7 \mathrm{~min}$ at $72^{\circ} \mathrm{C}$.

Amplified ribosomal DNA restriction analysis (ARDRA). The amplified rRNA PCR products of the correct size (approximately $1.3 \mathrm{~kb}$ ) were digested with Hin6I and MspI (Fermentas) overnight at $37^{\circ} \mathrm{C}$. The resulting ARDRA products were separated by gel electrophoresis in $3.0 \%$ agarose. The ARDRA patterns were visualized by UV excitation. Jaccard coefficients were computed for all pairwise comparisons of ARDRA banding patterns, and dendrograms constructed using the unweighted pair group mean average method in Molecular Analyst version 1.1 (Bio-Rad). ARDRA banding patterns that were identified were grouped into an operational taxonomic unit (OTU), and a representative clone was selected for nucleotide sequence determination in each OTU.

Sequencing and phylogenetic analysis. After selecting clones in different ARDRA patterns, a total of 60 clones were sequenced by Sunbiotech (Beijing). Sequence identification was initially estimated at the BLASTN facility of the National Center for Biotechnology Information (www.ncbi. nlm.nih.gov/BLAST). The initial phylogenetic trees were based on all available sequences and were constructed using the DNA distance neighbor-joining program with Felsenstein correction in ARB (Smith et al. 1994). After appropriate subsets of 16S rRNA gene sequences were selected, analyzed, and aligned with CLUSTAL-X (version 1.8) based on the initial phylogenetic results, the final phylogenetic trees were generated.
Statistical analysis. Principal component analysis (PCA) was performed using the SYSTAT version 13.0 (SPSS) and by consulting protocols described by Bagwell et al. (2006) and Palumbo et al. (2004) for each sampling site. PCA simultaneously considers many correlated variables and identifies the lowest number required to accurately represent the structure of the data. These variables are then linearly combined with the eigenvectors of the correlation matrix to generate a principal component axis. In the present study, PCA was used to group or separate stations, which did or did not differ based on their biogeochemical parameters $(\mathrm{pH}$, temperature, mercury, arsenic, phosphorus, cobalt, magnesium, copper, tungsten, zinc, lead, manganese, silver, sulphur, molybdenum, chromium, iron, aluminium, tin, calcium, potassium). Biogeochemical parameters were entered into the Data Editor of SPSS, and PCA analysis was performed according to the SPSS manual. The whole analysis was run automatically after data were entered, and all data were auto-standardized by SPSS. The conditions of the analysis were correlation matrix, unrotated factor solution, 2 factors, maximum iterations for convergence $=25$. Output data were plotted in 2 dimensions. The PCA results were applied to ascertain which biogeochemical parameters contributed to the differences among stations. Similarly, the correlation analysis was applied to the biological parameters, whereby the relative amount of each OTU (unique ARDRA pattern) for each station was used as a variable.

The rarefaction analysis was performed with SigmaPlot version 8.0 software. An exponential model, $y=a[1-\exp (-b x)]$, was applied in SigmaPlot to fit the clone distribution data. SAS was used primarily for PCA of the clone data.

Because the reciprocal of Simpson's index $(1 / D)$ has a good to moderate discriminating ability, and is used widely in ecological studies (Magurran 1988), it was chosen to characterize the microbial communities in our AMD samples. The use of $1 / D$ instead of the original formulation of Simpson's index ensures that an increase in the reciprocal index reflects an increase in diversity (Magurran 1988, Zhou et al. 2002).

\section{RESULTS}

\section{Biogeochemical properties of stations}

The biogeochemical properties of the AMD samples from Dabaoshan Mine are summarized in Table 1. The temperature at Sites LC and FS stabilized at around $22^{\circ} \mathrm{C}$ in the daytime. Because Site JX was underground, temperature here was maintained at $20^{\circ} \mathrm{C}$ all year round. The $\mathrm{pH}$ values were very similar to each other, ranging from 1.9 to 2.3 (Table 1 ). 
Table 1. Biogeochemical properties of AMD samples

\begin{tabular}{|c|c|c|c|}
\hline $\begin{array}{l}\text { Parameter (all } \\
\text { elements in } \mathrm{mg} \mathrm{l}^{-1} \text { ) }\end{array}$ & JX & $\begin{array}{l}\text { Site } \\
\text { LC }\end{array}$ & FS \\
\hline $\mathrm{pH}$ & 2.3 & 2.0 & 1.9 \\
\hline Temperature $\left({ }^{\circ} \mathrm{C}\right)$ & 20 & 22 & 22 \\
\hline $\mathrm{Hg}$ & 0.83 & 0.89 & 2.51 \\
\hline As & 1.95 & 1.78 & 5.23 \\
\hline $\mathrm{P}$ & 3.95 & 4.22 & 13.28 \\
\hline Co & 0.65 & 2.66 & 1.43 \\
\hline $\mathrm{Mg}$ & 643 & 344 & 733 \\
\hline $\mathrm{Cu}$ & 13.9 & 1120 & 2762 \\
\hline W & 2.89 & 4.15 & 9.71 \\
\hline Zn & 55.86 & 59.98 & 287 \\
\hline $\mathrm{Pb}$ & 3.13 & 4.19 & 7.39 \\
\hline $\mathrm{Mn}$ & 50.55 & 151 & 150 \\
\hline $\mathrm{Si}$ & 30.15 & 59.34 & 63.79 \\
\hline $\mathrm{Ag}$ & 0.3 & 0.37 & 0.39 \\
\hline $\mathrm{S}$ & 2719 & 2881 & 10266 \\
\hline Mo & 0.47 & 0.51 & 1.26 \\
\hline $\mathrm{Cd}$ & 0.59 & 0.5 & 3.35 \\
\hline $\mathrm{Fe}^{3+}$ & 378.9 & 120.6 & 6331.5 \\
\hline $\mathrm{Fe}^{2+}$ & 6.0 & 136.5 & 6.5 \\
\hline $\mathrm{Al}$ & 429.1 & 391.5 & 1506 \\
\hline $\mathrm{Ti}$ & 0.16 & 0.15 & 0.22 \\
\hline $\mathrm{Sn}$ & 0.87 & 0.92 & 2.6 \\
\hline $\mathrm{Sb}$ & 2.4 & 2.61 & 6.03 \\
\hline $\mathrm{Ni}$ & 0.85 & 2.78 & 2.8 \\
\hline $\mathrm{Cr}$ & 0.27 & 0.49 & 0.66 \\
\hline $\mathrm{Ca}$ & 392 & 511 & 285 \\
\hline K & 10.84 & 6.08 & 3.08 \\
\hline
\end{tabular}

\section{ARDRA analysis of $16 \mathrm{~S}$ rRNA clone libraries}

In this study, clones containing partial 16S rRNA gene inserts were obtained from the direct cloning of PCR products, which were copied from the genomic DNA isolated from each of the different AMD samples. From each sample, 124 to 128 clones were chosen randomly, and the PCR products of 16S rRNA gene fragments inserted into these clones were hydrolyzed by the restriction enzymes Hin6I and MspI. The ARDRA analysis revealed extensive phylogenetic diversity in 16S rRNA for all 3 samples examined (Fig. 1). Nine OTUs (Nos. 4, 5, 6, 10, 23, 25, 31, 38 and 46) were common to all 3 samples, and dominant 16S rRNA clones were detected for each sample.

In Sample JX, 42 OTUs were detected and 2 OTUs (Nos. 5 and 23) were frequently recovered, accounting for 14.5 and $13.7 \%$ of the clone library respectively. Moreover, 20 OTUs had a single clone.

In Sample LC, OTU No. 6 was the most dominant OTU and represented $56 \%$ of the clone library. OTU No. 46 was also dominant in the sample, representing $29.6 \%$ of the clone library. The other 15 OTUs in Sample LC jointly represented $14.4 \%$ of all clones.

In Sample FS, OTU No. 5 accounted for $19.5 \%$ of the clone library; 3 other OTUs (Nos. 9, 57, 37) were also dominant, respectively representing $11.7,10.9$, and $10.2 \%$ of all FS clones.

Among these samples, the greatest number of unique clones was found in Sample JX (42 clones). Sample FS had 34 unique clones, and Sample LC contained the lowest number of unique 16S rRNA gene sequences (only 17 clones).
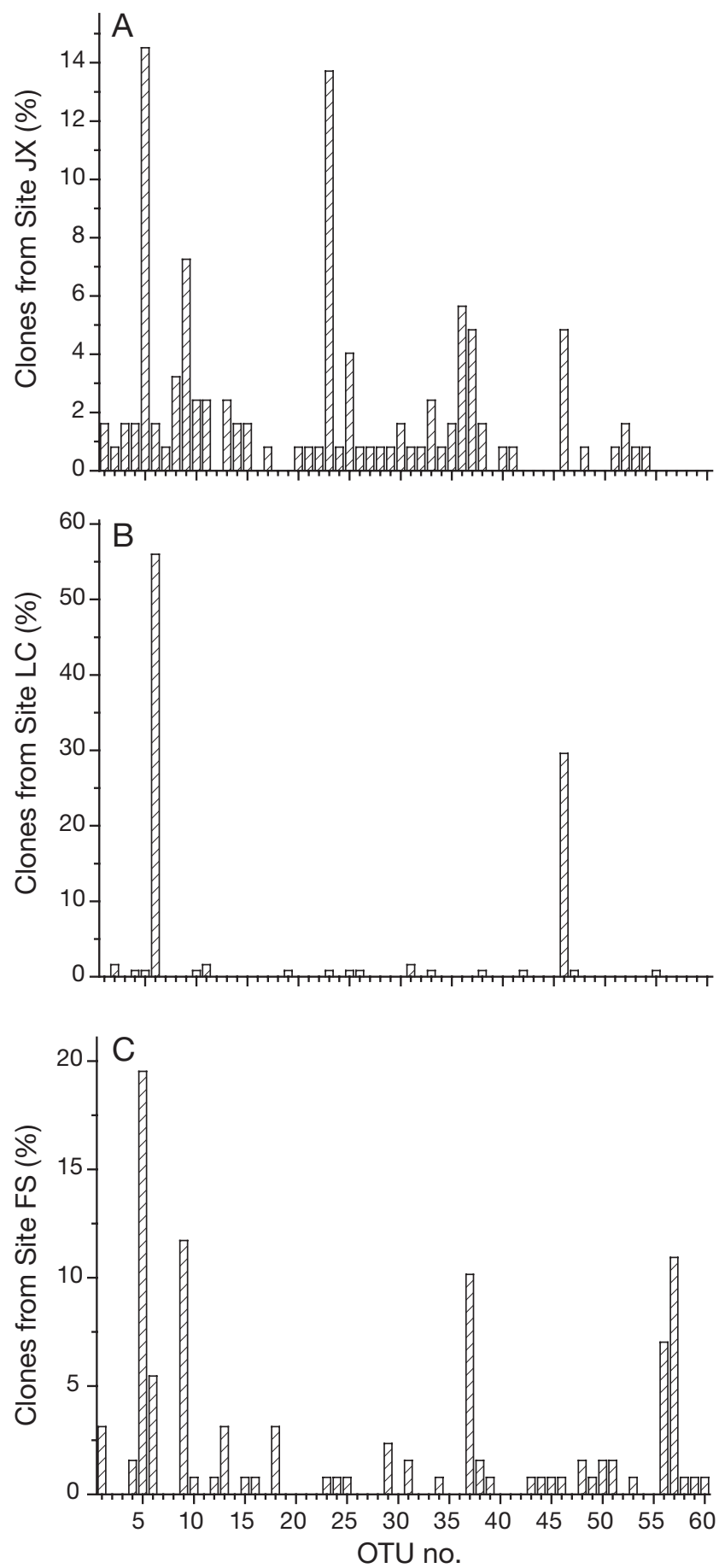

Fig. 1. Percentage of clones in (A) Sample JX, (B) Sample LC, and (C) Sample FS 
Rarefaction curves (plots of the cumulative number of OTUs as a function of a clone number) indicated that the majority of the OTUs in the samples were detected (Fig. 2). While more than $90 \%$ of the OTUs were detected within the first twenty 16S rRNA clones for Sample LC, less than $10 \%$ of the total OTUs were detected among the remaining $80 \%$ of clones. Moreover, while more than $80 \%$ of the OTUs were detected within the first 60 clones of the remaining samples, less than $20 \%$ of the total OTUs were detected among the remaining $\sim 50 \%$ of clones. This suggests that the level of analysis was sufficient to detect the community diversity and infer the distribution within these communities.

\section{Phylogenetic analysis}

To determine the phylogenetic diversity, representative $16 \mathrm{~S}$ rRNA clones were sequenced. Comparative sequence analysis was conducted on nucleotide sequences (on average, 1310 comparable positions for 16S rRNA gene). The major sequences of the clones differed by less than $5 \%$ from those in current databases. The phylogenetic relationships of samples from all 3 sites was established with a bootstrap neighborjoining method using the sequences from all known and candidate divisions (Fig. 3). These sequences fell into 5 main putative phylogenetic divisions, Acidobacteria, Acitinobacteria, Nitrospira, Alphaproteobacteria and Gammaproteobacteria, which amounted to OTUs of 2, 2, 16, 22 and 18, respectively. Clones were affiliated with Gammaproteobacteria (47.5\%), Alpha-

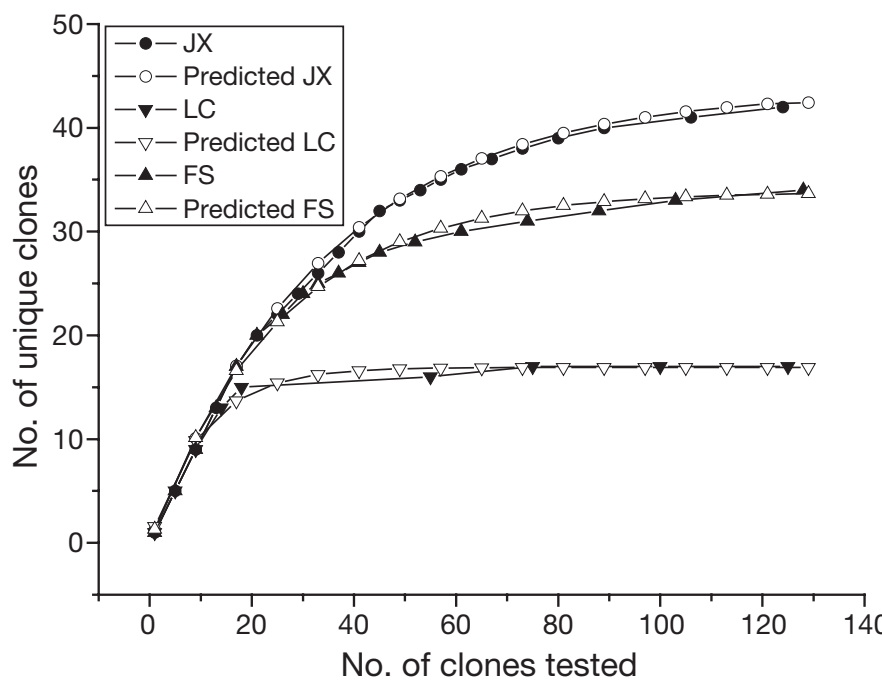

Fig. 2. Rarefaction curves for the different ARDRA patterns of all clones used in this study. The expected number of ARDRA patterns is plotted versus the actual number of patterns proteobacteria $(29.4 \%)$ or Nitrospira $(19.5 \%)$, except a few clones that were affiliated with Acidobacteria $(2.5 \%)$ and Acitinobacteria (1.1\%). No clones were affiliated with Firmicutes or Betaproteobacteria.

\section{Acidobacteria}

Phylogenetic analysis indicated that clone Nos. 14 and 25 fell into the Acidobacteria group. DBS(Dabaoshan mine)-Clone 14 exhibited $95 \%$ identity with IMAMD Clone BA2 (Druschel et al. 2004), and DBSClone 25 showed $98 \%$ identity with Acidobacteriaceae strain WJ7, isolated from remediate mine drainage (Hallberg \& Johnson 2003). Each sample in this group contained DBS-Clone 25.

\section{Actinobacteria}

Actinobacteria was detected in LC and FS samples. The clones (Nos. 21 and 29) associated with Actinobacteria fell into 1 group. DBS-Clone 21 shared $93 \%$ identity with Actinobacterium WJ25, and DBS-Clone 29 shared $99 \%$ identity with Ferrimicrobium acidiphilum strain T23, a heterotrophic iron-oxidizing acidophile from acid mine waters.
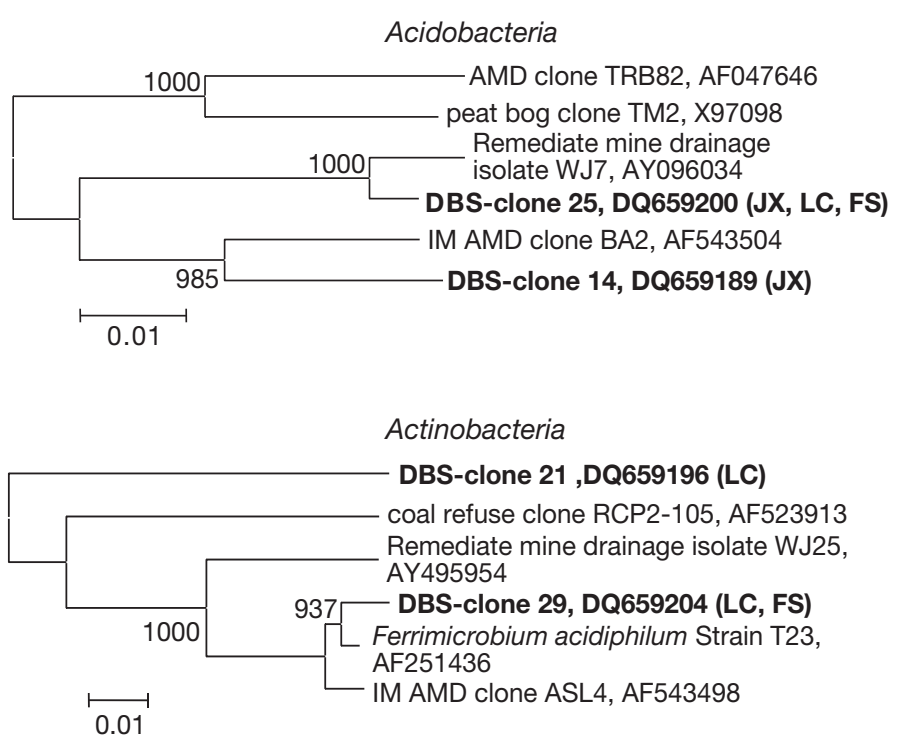

Fig. 3. (above and following 3 pages) Phylogenetic relationship of partial 16S rDNA sequences generated in this study. Scale bar represents the number of changes per base position. Numbers at tree nodes represent the number of times the topology to the right of the node was recovered in 1000 bootstrap resamplings. Clone names in bold correspond to sequences determined in the present study. JX: Site JX; LC: Site LC; FS: Site FS; IM: Iron Mountain 


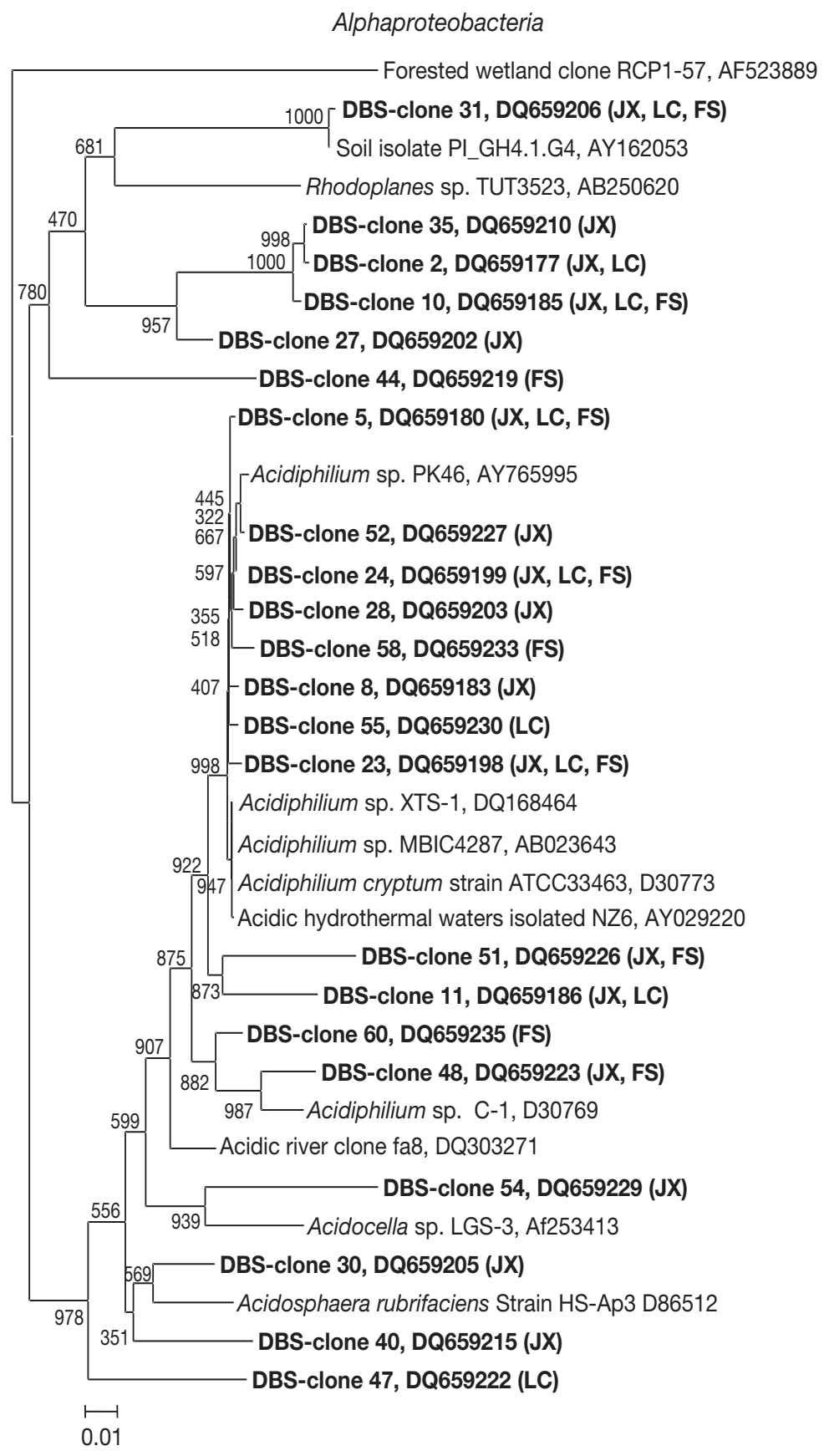

Fig. 3 (continued)

Leptospirillum

Within the Leptospirillum, clones fell into 3 major groups. The most abundant group was affiliated with Leptospirillum ferriphilum $(17.2 \%$ in the total clone library and $90 \%$ of all Nitrospira clones). Within Leptospirillum Group I, clones (Nos. 1, 12, 56, 13, 36, 45, $49,39,57,9,19,43$ and 50) all showed 295 to $99 \%$ identity with known L. ferrooxidans. However, within Leptospirillum Group II, only DBS-Clone 59 was detected. Two clones (Nos. 17 and 18) were associated with Leptospirillum Group III, but only represented a small branch of the phylogenetic tree.

\section{Alphaproteobacteria}

Alphaproteobacteria was another common group found in acid drainage waters. Kusel et al. (1999) isolated 6 species of heterotrophic Alphaproteobacteria of the genus Acidiphilum, which was originally isolated from acidic iron-rich sediment from a lake associated with a coal mine in eastern Germany. Within the Alphaproteobacteria, the major clones were affiliated with Acidiphilium sp. (20.1\% in the total clone library and $68.3 \%$ of all Alphaproteobacteria clones). The Alphaproteobacteria could be divided into 3 groups. The first group was closely related to Acidiphilium spp. The major clones clustered well into this group and were very similar ( 97 to $99 \%$ ) to known Acidiphilium sp. Only 4 clones were affiliated with the second group: three shared $\sim 90$ to $95 \%$ identity with Acidosphaera rubrifaciens, while 1 clone was affiliated with Acidocella sp. LGS-3 (95\% identity). In the third group, 6 clones were associated with Rhodoplanes sp. ( 90\% identity), and DBS-Clone 31 shared $99 \%$ identity with Alphaproteobacteria PI_GH4.1.G4, which was isolated from a soil sample (Zengler et al. 2002).

\section{Gammaproteobacteria}

Gammaproteobacteria have been found to be the dominant species in many AMD environments (Johnson et al. 2002, Johnson \& Hallberg 2003) Within the Gammaproteobacteria, the major clones were affiliated with Acidithiobacillus ferrooxidans (37.9\% in the total clone library and $79.8 \%$ of all Gammaproteobacteria clones). All clones related to the Gammaproteobacteria fell into 4 major groups. The first group was affiliated with Acidithiobacillus species. In this group, all clones exhibited 98 to 99\% identity with $A$. ferrooxidans. Four clones (Nos. 37, 53, $34,22)$ were clustered with the second group, and were closely related to the Gammaproteobacterium WJ2 with identities of $\sim 95$ to $99 \%$. Four clones (Nos. 41, 3, 20, 16) were clustered with the third group, and were related to Legionella species but to a lesser 


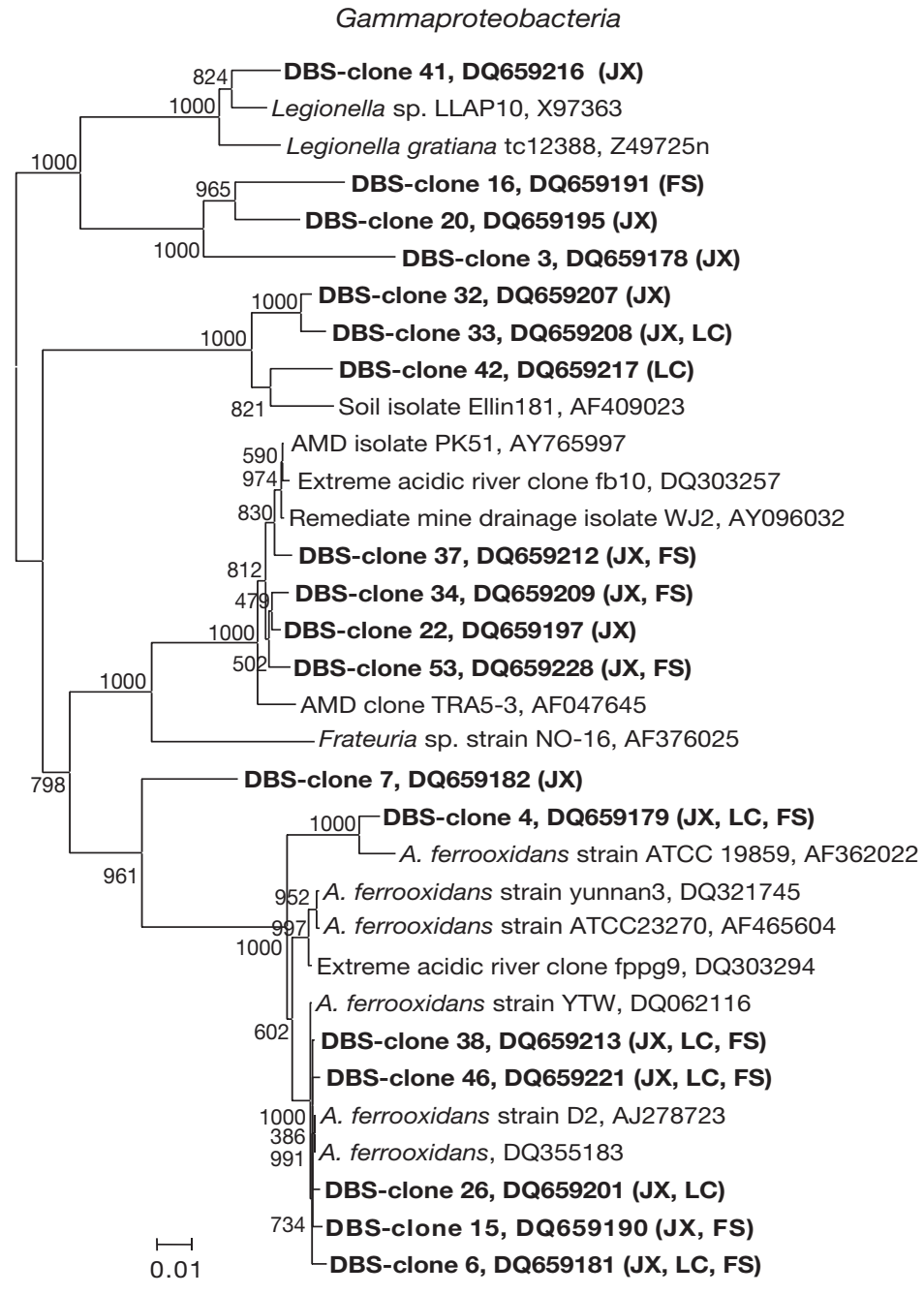

Fig. 3 (continued, and overleaf)

extent ( 89 to $97 \%$ identity). The last 3 sequences were clustered with the fourth group and affiliated with soil isolate Ellin181 ( 95 to 97\% identity).

\section{Nucleotide sequence accession numbers}

The 16S rRNA gene sequences of DBS-Clone 1 to DBS-Clone 60 described in this study were submitted to GenBank under accession numbers DQ659176 to DQ659235.

\section{Statistical analysis}

PCAs based on the 60 bacterial units captured virtually all of the variability in the clones' data. Approximately $88.21 \%$ of the variability in the 31 bacterial units used in the analysis was represented in the PCs. The first PC
(PC1) captured $54.02 \%$ of the variability, and PC2 captured $34.19 \%$ of the variability. In the PCA (Fig. 4), the biogeochemical properties of Samples JX and LC were similar yet significantly different from those of Sample FS. According to the PCA (Fig. 5), the overall bacterial community structures of Samples JX and FS were more similar to each other than to those of Sample LC. Calculations of diversity revealed that the diversity of Sample LC $(1 / D=2.51)$ was the lowest, the diversity of Sample FS $(1 / D=12.35)$ intermediate, and the diversity of Sample JX $(1 / D=18.42)$ the highest.

\section{Structure of bacterial communities}

We identified major bacterial components in 3 AMD samples. Previous studies of AMD identified major bacterial lines of descent as divisions within the Proteobacteria, Nitrospira, Firmicutes, Actinobacteria and Acidobacteria (Baker \& Banfield 2003, Johnson \& Hallberg 2003). In our study, Proteobacteria, Nitrospira, Actinobacteria and Acidobacteria were found, but Firmicutes was absent. However, the diversity of bacterial communities clearly differed among the 3 samples.

In Sample JX, the dominant bacterial communities were $38.7 \%$ Acidiphilium sp. (38.7\%), Leptospirillum ferriphilum (16.9\%) and Acidithiobacillus ferrooxidans $(12.1 \%)$. The percentage contributions of other Gammaproteobacteria, Alphaproteobacteria, Acidobacteria, Actino- bacteria and Leptospirillum were 14.5, $8.9,5.6,1.6$ and $0.8 \%$, respectively.

In Sample LC, the majority of these clones (88.0\%) belonged to Acidithiobacillus ferrooxidans. The percentage contriubtions of Acidiphilium sp., other Alphaproteobacteria, Gammaproteobacteria, Leptospirillum ferriphilum and Acidobacteria were 4, 4.8, 1.6, 0.8 and $0.8 \%$, respectively.

In Sample FS, the dominant bacterial community was composed of $39.1 \%$ Leptospirillum ferriphilum, $25.8 \%$ Acidiphilium sp. and 10.2\% Acidithiobacillus ferrooxidans. The percentage contributions of Gammaproteobacteria, Leptospirillum, Alphaproteobacteria, Actinobacteria and Acidobacteria were 12.5, $6.3,3.1,2.3$ and $0.8 \%$, respectively.

\section{DISCUSSION}

To quantitatively measure diversity in the samples, we used the inverse of Simpson's index $(1 / D)$, which is 


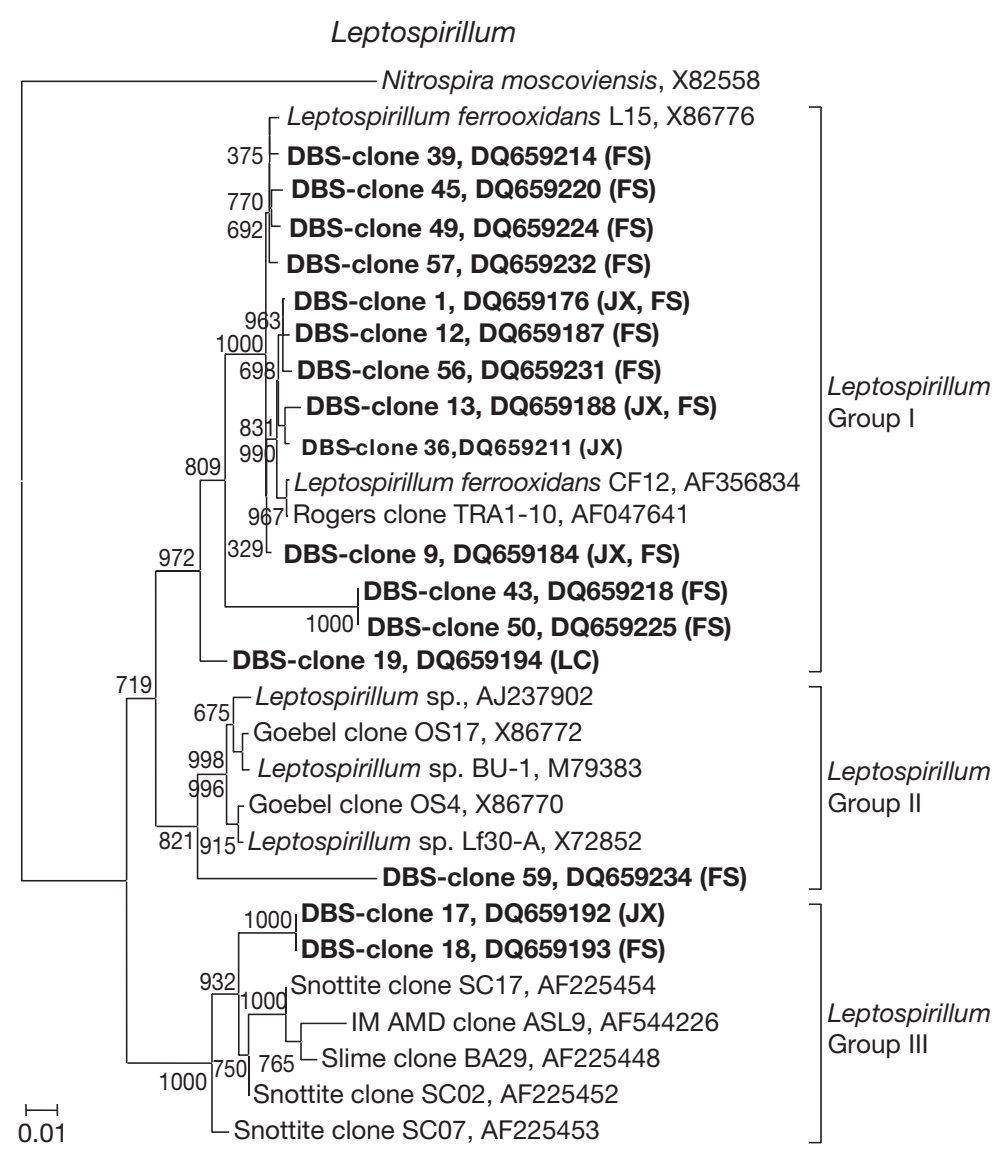

Fig. 3 (continued)

sensitive to the level of dominance in a community (Magurran 1988). The reciprocal of Simpson's index $(1 / D=2.51$ to 18.42$)$ effectively proved that bacterial community diversities of AMD were much lower than those of other environments, such as surface soils and

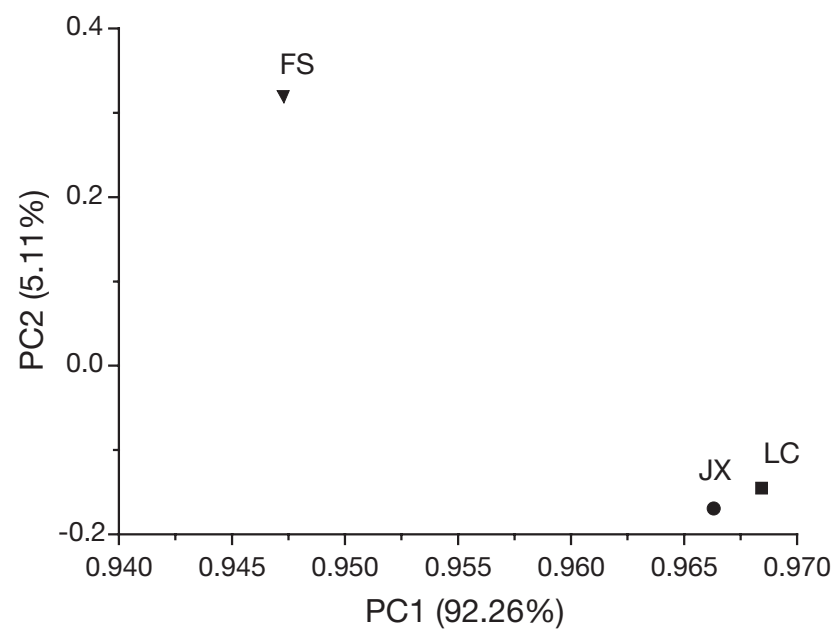

Fig. 4. Ordination plots from PCA of biogeochemical properties of Samples JX, LC and FS. Values in parentheses indicate variance marine sediments. Zhou et al. (2002) showed that $1 / D$ values in surface soils ranged from 507 to 27331, while Ravenschlag et al. (1999) demonstrated that bacterial diversity in permanently cold marine sediments was high. The $1 / D$ value of actinobacterial diversity was 51 , even 5 to $12 \mathrm{~cm}$ below the sea floor at a depth of $3814 \mathrm{~m}$ (Stach et al. 2003). It is noteworthy that AMD environments examined in the present study exhibited very low microbial diversity indices because of high ion concentrations and low $\mathrm{pH}$. However, bacterial diversities were obviously distinct among different AMD sites: $1 / D$ values were 2.51 and 18.42 in Samples LC and JX respectively. This phenomenon - variable diversities among samples - has also been observed in some other studies. For example, the community of Sample LC exhibited low OTU diversity and greater dominance by fewer OTUs, which is similar to the pattern observed in low-carbon vadose zone sediments: some $1 / D$ values of the saturated subsurface soil communities at low-carbon sites ranged from just 13 to 25 , while others ranged from 70 to 27331 (Zhou et al. 2002).

Some species of Actinobacteria, which were isolated from a forested wetland impacted by reject coal (Brofft et al. 2002) and the AMD environments of Wheal Jane (Johnson et al. 2002) and Iron Mountain (Nordstrom et al. 2000), were also detected in samples from Sites LC and FS in Dabaoshan Mine, China. Acidobacteria is a genus of very important microbes in AMD ecology, which performs an indispensable function in the formation of AMD. Moreover, Acidobacteria exists in relatively moderate AMD environments $\left(20\right.$ to $37^{\circ} \mathrm{C}$ and $\mathrm{pH}$ of 3.0 to 6.0), and some analyses suggested that this group is limited to environments of high $\mathrm{pH}(\mathrm{pH}>1.4)$ (Druschel et al. 2004). Druschel et al.'s (2004) study is in accordance with our results: Acidobacteria was found in samples from all 3 sites.

A heterotrophic bacterial species, Acidiphilium sp., was found in samples from all sites. Acidiphilium sp. is considered able to adapt to temperatures ranging from 17 to $45^{\circ} \mathrm{C}$, and to $\mathrm{pH}$ values ranging from 1.5 to 6.0 (Baker \& Banfield 2003). Peccia et al. (2000) suggested that there might be a mutualistic relationship between Thiobacillus sp. and Acidiphilium sp. Acidiphilium sp. was reported along with iron- and sulfur-oxidizing chemolithoautotrophs and in extreme acidic environments (Harrison 1984, Gonzalez-Toril et al. 2003b). These microorganisms may play a critical role in such ecosystems. For example, some studies proposed that 


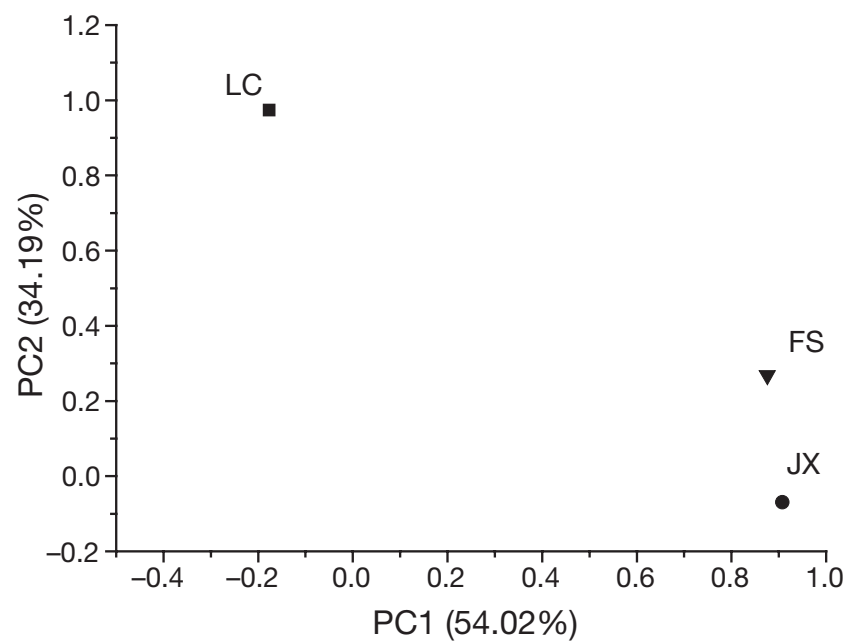

Fig. 5. Ordination plots from PCA of bacterial community structure of Samples JX, LC and FS. Values in parentheses indicate variance

Acidiphilium sp. could remove organic toxic compounds for Leptospirillum and Acidithiobacillus (Johnson 1995). Meanwhile, the physiological and ecological capabilities of Acidiphilium sp., which can utilize a variety of substrates and reduce ferric iron both in the presence and absence of oxygen, also indicates its important ecological roles in AMD, especially in the turnover of iron at oxic-anoxic interfaces (Kusel et al. 1999) .

Acidithiobacillus ferrooxidans and Leptospirillum ferrooxidans are widely considered to be the microorganisms that control the rate of generation of AMD, and have been used as model species of leaching environments (Fowler et al. 1999, Rohwerder et al. 2003). To date, Leptospirillum isolates and environmentallyderived clones cluster within 1 of 3 phylogenetic distinct groups (Bond et al. 2000): L. ferrooxidans (Group I) (Hippe 2000); L. ferriphilum (Group II) (Coram \& Rawlings 2002); and Leptospirillum Group III, which was only detected via clone library analysis of Iron Mountain bacterial communities (Bond et al. 2000, Druschel et al. 2004). In our study, Leptospirillum Group I sequences were discovered at all sites, and were dominant in 3 Leptospirillum groups. Only 1 sequence was affiliated with Group II in Sample FS, while only 1 and 2 sequences were affiliated with Group III in Samples JX and FS respectively. L. ferrooxidans (Group I) is reported to grow within an opti$\mathrm{mal} \mathrm{pH}$ range of 1.6 to 2.0 (compared with 1.4 to 1.8 for L. ferriphilum) (Coram \& Rawlings 2002). L. ferriphilum and Leptospirillum Group III primarily reside in lower $\mathrm{pH}$ microenvironments within mines, while $L$. ferrooxidans occurs in higher $\mathrm{pH}$ environments $(\mathrm{pH}>$ 1) (Druschel et al. 2004). Therefore, the high $\mathrm{pH}$ values ( $\mathrm{pH}>1.8)$ in the 3 samples were likely the reason why
Leptospirillum Groups II and III were rarely represented.

Acidithiobacillus ferrooxidans-like bacteria were also found to be the dominant iron-oxidizers in a stream draining the former King's copper mine in Roeros, Norway (Johnson et al. 2001). By using FISH (fluorescence in situ hybridization) probes, Schrenk et al. (1998) showed that A. ferrooxidans is abundant in environments with temperatures $<30^{\circ} \mathrm{C}$ and $\mathrm{pH}>1.3$ at Richmond Mine. Edwards et al. (1999) also found $A$. ferrooxidans at greatest abundance $(>30 \%)$ at moderate temperature $\left(2.5\right.$ to $\left.20^{\circ} \mathrm{C}\right)$ and $\mathrm{pH}(1.5$ to 2.3$)$ at sites that were peripheral to primary acid-generating sites. In our study, Sample LC $\left(\sim 22^{\circ} \mathrm{C}, \mathrm{pH} 2.0\right)$ was so favorable for $A$. ferrooxidans that it became the most dominant microbe (88.0\% of the bacterial population) - a result that is in good accordance with the report of Edwards et al. (1999). However, in Sample JX $\left(\sim 20^{\circ} \mathrm{C}\right.$, $\mathrm{pH} 2.3)$ and Sample FS ( 22 $\left.{ }^{\circ} \mathrm{C}, \mathrm{pH} 1.9\right), \mathrm{pH}$ values and temperatures were similar to those of Sample LC, but A. ferrooxidans represented only 12.1 and $10.2 \%$ of the bacterial population, respectively, and L. ferrooxidans was instead more dominant (representing 16.9 and $39.1 \%$, respectively). These results differ from those of Schrenk et al. (1998) and Edwards et al. (1999). Thus, factors other than temperature and $\mathrm{pH}$ are likely to have important effects on bacterial community structure in AMD.

In samples from all 3 sites, the correlation between bacterial communities and physiochemical characteristics seemed to be indistinct. Samples JX and LC had similar biogeochemical properties (see Fig. 5), but bacterial communities obviously differed (Fig. 6). In contrast, Samples JX and FS were dissimilar in biogeochemical properties (Fig. 5) but similar in bacterial community composition (Fig. 6). However, it is notable that the concentration of ferrous iron in Sample LC greatly exceeded those in Samples JX and FS (fresh minerals were being mined continuously at Site LC). As is well known, ferrous iron is a key energy substance for many bacterial species. However, with the exception of Acidithiobacillus ferrooxidans, other bacterial species capable of making use of ferrous iron were little-represented in Sample LC (e.g. Leptospirillum ferrooxidans only represented $0.8 \%$ of the total clones). We suggest that $A$. ferrooxidans grows first under conditions of high ferrous iron concentrations. Some previous studies support our inference: McGinness \& Johnson (1993) found that A. ferrooxidans was the most numerous iron-oxidizer present in AMD draining the abandoned Cae Coch pyrite mine in north Wales, where ferrous iron concentrations were often $>500 \mathrm{mg} \mathrm{l}^{-1}$. L. ferrooxidans has a higher affinity for $\mathrm{Fe}^{2+}$, and this species was particularly numerous when ferrous iron concentrations were $<10 \mathrm{mg} \mathrm{l}^{-1}$. In our 
study, A. ferrooxidans was particularly numerous in Sample LC $\left(\mathrm{Fe}^{2+}\right.$ concentration $\left.=136.5 \mathrm{mg} \mathrm{l}^{-1}\right)$, while $L$. ferrooxidans was more abundant than A. ferrooxidans in Samples JX and FS $\left(\mathrm{Fe}^{2+}\right.$ concentration $=6.0$ and $6.5 \mathrm{mg} \mathrm{l}^{-1}$, respectively). Thus, in our study, ferrous iron might be a factor that affected bacterial community structure. Sand et al. (1992) noted that in their bioreactors, high ratios of $\mathrm{Fe}^{3+}$ to $\mathrm{Fe}^{2+}$ appeared to be less inhibitory to L. ferrooxidans than to A. ferrooxidans. This may also have been the case in our study.

Furthermore, the amounts of many elements (e.g. $\mathrm{Hg}, \mathrm{Mg}, \mathrm{Cu}, \mathrm{As}, \mathrm{Pb}, \mathrm{S}, \mathrm{Fe}, \mathrm{Al}$ ) in Sample FS were much higher than the other 2 samples. The primary reason for this was that Site FS was used to deposit many abandoned ores for a long period of time, and many ores were dissolved into water by chemical- and microbe-mediated dissolution. Thus, the concentration of toxic ions in AMD at Site FS may have been correlated with time. In addition, the percentage of Leptospirillum spp. in Sample FS was the highest, but the percentage of Acidithiobacillus ferrooxidans the lowest. Dopson et al. (2003) showed that the growth of $A$. ferrooxidans will be limited when metal concentrations exceeded certain level, and some reports (Edwards et al. 1999, Bond et al. 2000, Olson et al. 2003) have noted that Leptospirillum ferrooxidans has a stronger tolerance to toxic ions within a certain concentration range. Thus, toxic ions might represent another potential factor that affects bacterial community structure.

AMD is generated from mine solution and, in the process, a variety of geochemical properties lead to variable microbial ecology. Two factors that affect bacterial communities - the concentrations of ferrous iron and toxic ions - could be correlated with time. Therefore, AMD could be regarded as a dynamic environment, and the different bacterial community structures of 3 AMD samples could simply reflect different periods of an evolution process. Generally, changes in the bacterial community in AMD of a metal mine that was still in use were irregular, because the extant environmental conditions were affected by mining. However, after sites are left abandoned for a long time, the concentration of metal ions will increase slowly and regularly owing to the dissolution process of minerals, and the subsequent evolution of bacterial communities should progress slowly and regularly too. In the early stages, the bacterial species capable of rapidly using ferrous iron will become dominant in bacterial communities. However, with the accumulation of toxic ions, the bacterial species with strong resistance to toxic ions will gradually predominate. Of course, other factors (such as seasonal variations and drought) may also have important effects on this evolution. In the case of bioleaching, the effect of this factor on the bacterial community must be considered.
Acknowledgements. Thanks to Weiliang Chao, Department of Microbiology, Soochow University, Taipei, for invaluable suggestions. This work was supported by 973 Program of China (No. 2004CB619201) and the National Natural Science Foundation of China (NSFC No. 50621063).

\section{LITERATURE CITED}

Bagwell CE, Liu X, Wu L, Zhou J (2006) Effects of legacy nuclear waste on the compositional diversity and distributions of sulfate-reducing bacteria in a terrestrial subsurface aquifer. FEMS Microbiol Ecol 55:424-431

Baker BJ, Banfield JF (2003) Microbial communities in acid mine drainage. FEMS Microbiol Ecol 44:139-152

Bond PL, Smriga SP, Banfield JF (2000) Phylogeny of microorganisms populating a thick, subaerial, predominantly lithotrophic biofilm at an extreme acid mine drainage site. Appl Environ Microbiol 66:3842-3849

Brofft JE, McArthur JV, Shimkets LJ (2002) Recovery of novel bacterial diversity from a forested wetland impacted by reject coal. Environ Microbiol 4:764-769

Coram NJ, Rawlings DE (2002) Molecular relationship between two groups of the genus Leptospirillum and the finding that Leptosphillum ferriphilum sp. nov. dominates South African commercial biooxidation tanks that operate at 40 degrees C. Appl Environ Microbiol 68:838-845

Dopson M, Baker-Austin C, Koppineedi PR, Bond PL (2003) Growth in sulfidic mineral environments: metal resistance mechanisms in acidophilic micro-organisms. Microbiology 149:1959-1970

Druschel GK, Baker BJ, Gihring TM, Banfield JF (2004) Acid mine drainage biogeochemistry at Iron Mountain, California. Geochem Trans 5:13-32

Edwards KJ, Gihring TM, Banfield JF (1999) Seasonal variations in microbial populations and environmental conditions in an extreme acid mine drainage environment. Appl Environ Microbiol 65:3627-3632

Fowler TA, Holmes PR, Crundwell FK (1999) Mechanism of pyrite dissolution in the presence of Thiobacillus ferrooxidans. Appl Environ Microbiol 65:2987-2993

Golyshina OV, Pivovarova TA, Karavaiko GI, Kondrat'eva TF and 6 others (2000) Ferroplasma acidiphilum gen. nov., sp. nov., an acidophilic, autotrophic, ferrous-iron-oxidizing, cell-wall-lacking, mesophilic member of the Ferroplasmaceae fam. nov., comprising a distinct lineage of the Archaea. Int J Syst Evol Microbiol 50:997-1006

Gonzalez-Toril E, Gomez F, Rodriguez N, Fernandez-Remolar D, Zuluaga J, Marin I, Amils R (2003a) Geomicrobiology of the Tinto River, a model of interest for biohydrometallurgy. Hydrometallurgy 71:301-309

Gonzalez-Toril E, Llobet-Brossa E, Casamayor EO, Amann R, Amils R (2003b) Microbial ecology of an extreme acidic environment, the Tinto River. Appl Environ Microbiol 69:4853-4865

Hallberg KB, Johnson DB (2003) Novel acidophiles isolated from moderately acidic mine drainage waters. Hydrometallurgy 71:139-148

Harrison AP (1984) The Acidophilic thiobacilli and other acidophilic bacteria that share their habitat. Annu Rev Microbiol 38:265-292

Hippe H (2000) Leptospirillum gen. nov (ex Markosyan 1972), nom. rev., including Leptospirillum ferrooxidans sp. nov. (ex Markosyan 1972), nom. rev. and Leptospirillum thermoferrooxidans sp. nov. (Golovacheva et al. 1992). Int J Syst Evol Microbiol 50:501-503

Hurt RA, Qiu XY, Wu LY, Roh Y, Palumbo AV, Tiedje JM, 
Zhou JH (2001) Simultaneous recovery of RNA and DNA from soils and sediments. Appl Environ Microbiol 67: 4495-4503

Johnson DB (1995) Selective solid media for isolating and enumerating acidophilic bacteria. J Microbiol Methods 23:205-218

Johnson DB (1998) Biodiversity and ecology of acidophilic microorganisms. FEMS Microbiol Ecol 27:307-317

Johnson DB, Hallberg KB (2003) The microbiology of acidic mine waters. Res Microbiol 154:466-473

Johnson DB, Rolfe S, Hallberg KB, Iversen E (2001) Isolation and phylogenetic characterization of acidophilic microorganisms indigenous to acidic drainage waters at an abandoned Norwegian copper mine. Environ Microbiol 3:630-637

Johnson DB, Dziurla MA, Kolmert A, Hallberg KB (2002) The microbiology of acid mine drainage: genesis and biotreatment. S Afr J Sci 98:249-255

Kelly DP, Wood AP (2000) Reclassification of some species of Thiobacillus to the newly designated genera Acidithiobacillus gen. nov., Halothiobacillus gen. nov. and Thermithiobacillus gen. nov. Int J Syst Evol Microbiol 50: 511-516

Kormas KA, Tivey MK, Von Damm K, Teske A (2006) Bacterial and archaeal phylotypes associated with distinct mineralogical layers of a white smoker spire from a deepsea hydrothermal vent site (9 degrees N, East Pacific Rise). Environ Microbiol 8:909-920

Kusel K, Dorsch T, Acker G, Stackebrandt E (1999) Microbial reduction of $\mathrm{Fe}(\mathrm{III})$ in acidic sediments: isolation of Acidiphilium cryptum JF-5 capable of coupling the reduction of $\mathrm{Fe}(\mathrm{III})$ to the oxidation of glucose. Appl Environ Microbiol 65:3633-3640

Magurran E (1988) Ecological diversity and its measurement. Princeton University Press, Princeton, NJ

Marchesi JR, Sato T, Weightman AJ, Martin TA, Fry JC, Hiom SJ, Wade WG (1998) Design and evaluation of useful bacterium-specific PCR primers that amplify genes coding for bacterial 16S rRNA. Appl Environ Microbiol 64:795-799

Margesin R, Schinner F (2001) Potential of halotolerant and halophilic microorganisms for biotechnology. Extremophiles 5:73-83

McGinness S, Johnson DB (1993) Seasonal variations in the microbiology and chemistry of an acid-mine drainage stream. Sci Total Environ 132:27-41

Nordstrom DK, Alpers CN, Ptacek CJ, Blowes DW (2000) Negative $\mathrm{pH}$ and extremely acidic mine waters from Iron Mountain, California. Environ Sci Technol 34:254-258

Olson GJ, Brierley JA, Brierley CL (2003) Bioleaching review Part B: progress in bioleaching: applications of microbial processes by the minerals industries. Appl Microbiol Biotechnol 63:249-257

Editorial responsibility: Jed Fuhrman,

Los Angeles, California, USA
Palumbo AV, Schryver JC, Fields MW, Bagwell CE, Zhou JZ, Yan T, Liu X, Brandt CC (2004) Coupling of functional gene diversity and geochemical data from environmental samples. Appl Environ Microbiol 70:6525-6534

Peccia J, Marchand EA, Silverstein J, Hernandez M (2000) Development and application of small-subunit rRNA probes for assessment of selected Thiobacillus species and members of the genus Acidiphilium. Appl Environ Microbiol 66:3065-3072

Ravenschlag K, Sahm K, Pernthaler J, Amann R (1999) High bacterial diversity in permanently cold marine sediments. Appl Environ Microbiol 65:3982-3989

Rawlings DE (2002) Heavy metal mining using microbes. Annu Rev Microbiol 56:65-91

Rohwerder T, Gehrke T, Kinzler K, Sand W (2003) Bioleaching review Part A: progress in bioleaching: fundamentals and mechanisms of bacterial metal sulfide oxidation. Appl Microbiol Biotechnol 63:239-248

Russell NJ (2000) Toward a molecular understanding of cold activity of enzymes from psychrophiles. Extremophiles 4:83-90

Sand W, Rohde K, Sobotke B, Zenneck C (1992) Evaluation of Leptospirillum-Ferrooxidans for Leaching. Appl Environ Microbiol 58:85-92

Sand W, Gerke T, Hallmann R, Schippers A (1995) Sulfur chemistry, biofilm, and the (in)direct attack mechanism - a critical-evaluation of bacterial leaching. Appl Microbiol Biotechnol 43:961-966

Schrenk MO, Edwards KJ, Goodman RM, Hamers RJ, Banfield JF (1998) Distribution of Thiobacillus ferrooxidans and Leptospirillum ferrooxidans: implications for generation of acid mine drainage. Science 279:1519-1522

Smith SW, Overbeek R, Woese CR, Gilbert W, Gillevet PM (1994) The genetic data environment. An expandable GUI for multiple sequence analysis. Comput Appl Biosci 10: 671-675

Stach JEM, Maldonado LA, Masson DG, Ward AC, Goodfellow M, Bull AT (2003) Statistical approaches for estimating actinobacterial diverity in marine sediments. Appl Environ Microbiol 69:6189-6200

Suzuki I (2001) Microbial leaching of metals from sulfide minerals. Biotechnol Adv 19:119-132

Zengler K, Toledo G, Rappe M, Elkins J, Mathur EJ, Short JM, Keller M (2002) Cultivating the uncultured. Proc Natl Acad Sci USA 99:15681-15686

Zhou JZ, Bruns MA, Tiedje JM (1996) DNA recovery from soils of diverse composition. Appl Environ Microbiol 62: $316-322$

Zhou JZ, Xia BC, Treves DS, Wu LY, Marsh TL, O'Neill RV, Palumbo AV, Tiedje JM (2002) Spatial and resource factors influencing high microbial diversity in soil. Appl Environ Microbiol 68:326-334

Submitted: August 27, 2006; Accepted: March 7, 2007 Proofs received from author(s): April 16, 2007 